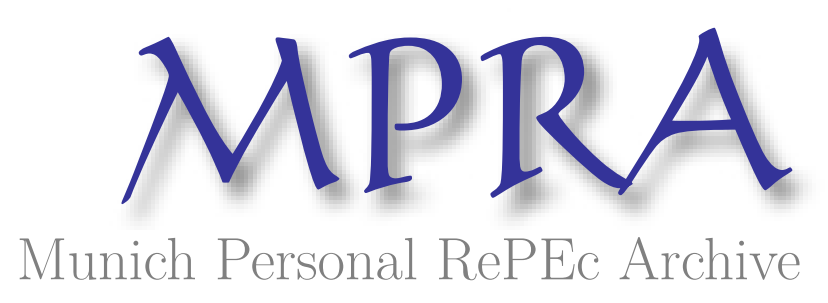

\title{
Alternate Proposal for Interest Free House Finance
}

Shaikh, Salman

IBA Karachi

1 January 2014

Online at https://mpra.ub.uni-muenchen.de/53804/

MPRA Paper No. 53804, posted 20 Feb 2014 12:50 UTC 


\title{
Alternate Proposal for Interest Free House Finance
}

\author{
Salman Ahmed Shaikh ${ }^{1}$
}

\begin{abstract}
In this paper, we present an alternate proposal for house finance. In our proposal, the Islamic bank buys the house paying the house owner the full amount of the house and becomes the owner. Then, the bank gives the house on rent to the client and the Islamic bank also enters into an options contract as the call option writer. If the call buyer does not exercise the option, the options contract expires and the Islamic bank is in a position to give the house on rent again. We present numerical examples of computing rents in two separate structures. In structure I, call option is used with the lease contract. In structure II, house is resold at market price with stated price floor. We show that the proposal is robust in different scenarios. Furthermore, it is substantially and meaningfully different from conventional finance in form and substance.
\end{abstract}

Keywords: Mortgages, House Finance, Personal Finance, Islamic Banking, Options, Diminishing Musharakah, Lease.

JEL Codes G21, G28

\section{Introduction}

Islamic finance has also been using the interest rate benchmark in pricing the assets and computing rents. The financial structure of products from cash flow perspective does not differ much in Islamic banking from conventional banking. It is argued that the difference lies in contract mechanics. As long as the prices are specified; method used for pricing the product is not a principal determinant of permissibility of a product structure in Islamic finance.

In currently used debt based modes of financing, Islamic bank does not commit a single penny unless the customer signs the unilateral undertaking, and by way of unilateral undertaking, the customer is bound to purchase the asset and pay bank markup price of the asset which is calculated using KLIBOR/LIBOR as a discount rate and using present value annuity formula.

Only when the customer agrees to provide that undertaking, will the bank think of purchasing the asset. Islamic bank basically amortizes all its costs through rentals or markup price. It is acting as a financial broker looking to amortize an investment made. For the same asset or property, bank will charge higher rentals for short term lease and lower for long term lease. It is because bank is willing to amortize all costs and not acting anything else than being a financial broker. The pricing for different tenures

\footnotetext{
${ }^{1}$ Salman Ahmed Shaikh is a Research Associate \& he teaches Economics courses at IBA, Karachi. He can be contacted at: salmanashaikh@iba.edu.pk
} 
mimics the term structure of interest rates and what enables comparable returns to the bank is the provision of locking second leg of transaction in all lease and trade based contracts using the 'unilateral undertaking' which by all means is legally binding.

In pricing products, Meera \& Dzuljastri (2009) showed that the mathematical derivation for the Islamic mortgage is similar to the formula used in conventional loans, but nonetheless with the interest rate replaced with the rental rate. Siti \& Azira (2013) investigating the house financing products offered in Malaysia disclosed that the bank still use conventional interest rate as a benchmark. Hasan (2012) also shared the same concern and concluded that the Islamic banks invariably use annuity formula to determine the fixed installment payments in home financing amortization. The formula has explicit compounding of return.

In this paper, we present a proposal of an alternate way to provide house finance which is different from conventional mortgage not only in form, but in substance as well. Going forward, section 2 gives account of current practice in conventional and Islamic finance to provide house financing. Section 3 presents the proposal. Section 4 gives the application of the proposal. Section 5 presents some numerical examples of computing rents in alternate scenarios.

\section{Current Practice}

In this section, we give an account of current practice in providing home finance both in conventional banking as well as in Islamic banking.

\subsection{Conventional Mortgage}

In conventional finance, bank after ensuring client's creditworthiness, provides loan to the client. The title of the house is immediately transferred to the client. However, the bank retains the right of foreclosure as recourse to recover the due amount of unpaid loan. The client pays the loan over the years usually in monthly installments. Each installment comprises two components, i.e. interest on balance due and principal repayment. Series of equal installments to be paid over the years by the client are computed using present value of annuity formula.

$$
P V A=A\left[\frac{(1+i)^{n}-1}{i(1+i)^{n}}\right]
$$

Where,

'PVA' is the amount of loan.

' $A$ ' is the periodic installment to be paid each period.

' $i$ ' is the interest rate.

' $n$ ' is the period of loan. 
In modern days and especially in last decade, several other features were added to the plain vanilla mortgage financing to lure the people into indebtedness. In some cases, there was no principal repayment required in initial years. In other cases, even no installment was to be paid in initial years. Different schemes also offered mortgage financing at multiple rates, with rates being considerably lower in initial years so that even the people with little income could also borrow.

What triggered the crisis in U.S. was the asset bubble in U.S. House market. House prices rose sharply after dot com bubble burst and touched the peak in 2005. When the house market bubble burst, house prices declined even sharply than the incline seen previously as shown in Figure 1.

Figure 1: U.S. House Price Index

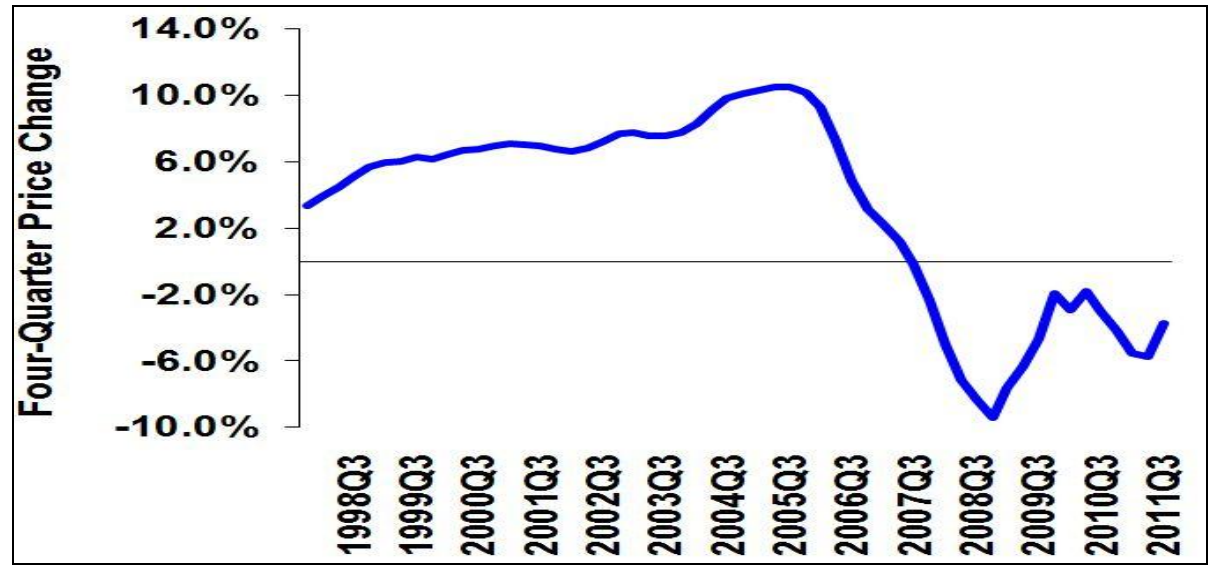

Source: Federal Housing Finance Agency

Bubble in house market was created after the steep decline in interest rates following recession in $2000 / 01$. Sharp decline in interest rates and predatory lending to sub-prime borrowers founded the beginning of the crisis as shown in Figure 2.

Figure 2: Short Term Rates (\%)

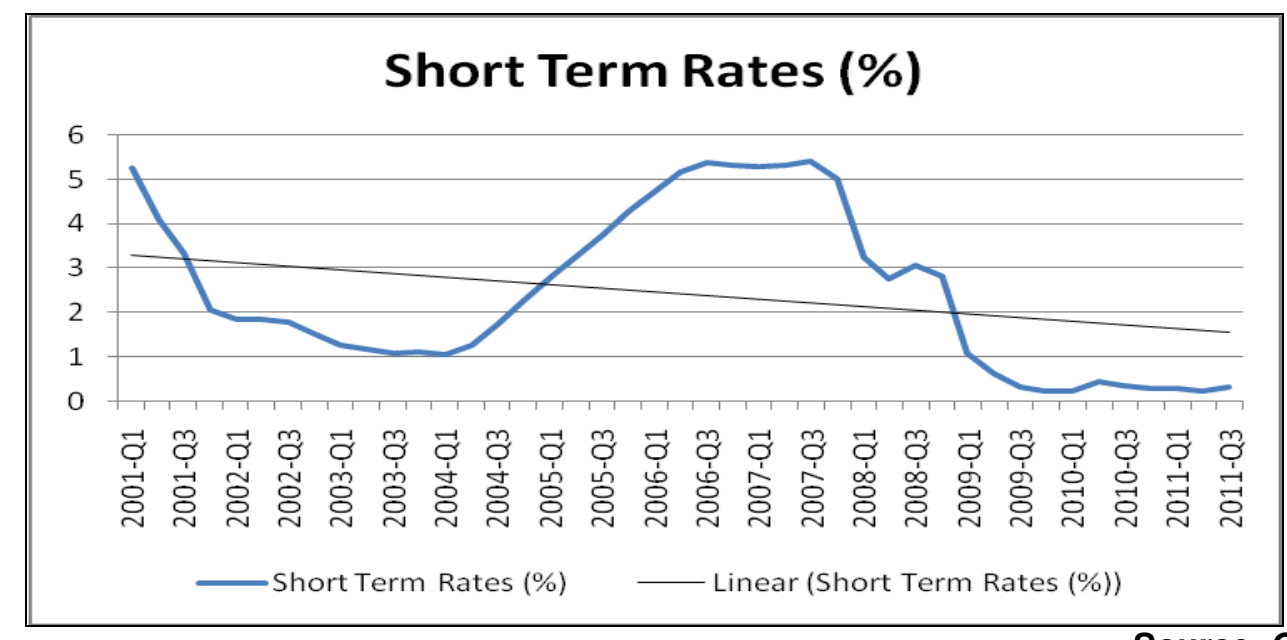

Source: OECD Stats

Page 3 of 13 
With the repeal of Glass Steagall act, the distinction between commercial and investment banking became ever more blurred. Commercial banks were able to mitigate risk by packaging risky consumer debt receivables and selling them to the investment banks. The investment banks securitized them and sold them to insurance companies, other investment banks, hedge funds etc. The underlying loans making up those securities were very risky. In some instances, loan was sanctioned at a loan to value ratio of $125 \%$. Adjustable rate mortgage, interest only mortgage etc and other luring schemes were offered to lend as much as was possible. Low interest rates provided the liquidity needed to keep the credit flowing.

With the rise in interest rates from 2005 onwards, many consumers could not pay their loans. Defaults increased and this had effects felt by all financial players who were part of this by way of insuring and holding securitized financial assets whose underlying assets were the same toxic loans.

\subsection{Diminishing Musharakah Structure}

In Diminishing Musharakah, the client approaches the bank for joint purchase of a house. Designated valuation agencies are consulted for the valuation of the house. The seller of the property is paid by the bank and the bank and the client enter into a Musharakah Agreement.

It is referred to as 'Diminishing Musharakah' because the ownership stake of the client (tenant of bank's share) increases and that of the bank decreases or diminishes with the regular payments paid by the client. The rent decreases as the ownership stake of the tenant increases.

The share of the bank in house is divided into units. These units are purchased by the client periodically until he has purchased all units and become the sole owner of the house. Rent is not charged immediately and is charged at the end of the month for the use of house. Rent for at least one period is fixed. Unit price fixed for a period will not change during that period. The rent is calculated based on 1 year KIBOR (Karachi Interbank Offered Rate).

In Musharakah Agreement, the floor rate (minimum rate) and the ceiling rate (maximum rate) is stated based on which the rent can vary. In Musharakah agreement, it is stated that if payments are made on time, the transfer of ownership will take place accordingly.

A numerical example will further explain this product structure. Table 1 presents the details. The formulas used to compute the results are listed below:

Number of units

Unit price (Rs.)

Rent per unit per Month $=($ Rental rate/12) $x$ unit price

Total rent per month $(\mathrm{Rs})=$ Rent per unit per month $(\mathrm{Rs}) \times$ no. of outstanding units

$=$ Tenure of lease in years $x$ number of months in year

$=$ Financing amount of asset required (Rs) / no. of units$$
\text { x no. of outstanding units }
$$

Page 4 of 13 
Total Starting Rent (Rs) = Total Rent per Month (Rs) + Unit Price

Table 1: Rental Computations in Islamic Mortgage

\begin{tabular}{|l|c|}
\hline \multicolumn{2}{|c|}{ Expected Rentals - House } \\
\hline Financing Amount of Asset Required (Rs) & $2,000,000$ \\
\hline Rental Rate (\%) & 15 \\
\hline Tenure of Lease (Years) & 5 \\
\hline & 60 \\
\hline No. of Units & $33,333.33$ \\
\hline Unit Price (Rs) & 416.67 \\
\hline Rent Per Unit Per Month (Rs) & 25,000 \\
\hline Total Starting Rent (Rs) & \\
\hline
\end{tabular}

Table 2 presents extract of a payment schedule. It can be seen that monthly payments are declining with decrease in rents. It is because the units in ownership of bank decrease with each additional unit purchased by client every month. Monthly interest payment in a conventional amortization schedule is replaced by monthly rent. Plus, the principal repayment in a conventional amortization schedule is replaced by unit price.

Table 2: Payment Schedule in Islamic Mortgage

\begin{tabular}{|c|c|c|c|c|c|}
\hline Month & $\begin{array}{c}\text { Monthly } \\
\text { Rent }\end{array}$ & $\begin{array}{c}\text { Per Unit } \\
\text { Price }\end{array}$ & $\begin{array}{c}\text { Monthly } \\
\text { Payment }\end{array}$ & $\begin{array}{c}\text { Balance } \\
\text { Units }\end{array}$ & $\begin{array}{c}\text { Balance Unit } \\
\text { Value }\end{array}$ \\
\hline 0 & & & & 60 & $2,000,000$ \\
\hline 1 & $25,000.00$ & $33,333.33$ & $58,333.33$ & 59 & $1,966,666$ \\
\hline 2 & $24,583.33$ & $33,333.33$ & $57,916.66$ & 58 & $1,933,333$ \\
\hline 3 & $24,166.67$ & $33,333.33$ & $57,500.00$ & 57 & $1,900,000$ \\
\hline 4 & $23,750.00$ & $33,333.33$ & $57,083.33$ & 56 & $1,866,666$ \\
\hline 5 & $23,333.33$ & $33,333.33$ & $56,666.66$ & 55 & $1,833,333$ \\
\hline & & & & & 133,333 \\
\hline 56 & $2,083.33$ & $33,333.33$ & $35,416.66$ & 4 & 100,000 \\
\hline 57 & $1,666.67$ & $33,333.33$ & $35,000.00$ & 3 & 66,667 \\
\hline 58 & $1,250.00$ & $33,333.33$ & $34,583.33$ & 2 & 33,333 \\
\hline 59 & 833.33 & $33,333.33$ & $34,166.66$ & 1 & - \\
\hline 60 & 416.67 & $33,333.33$ & $33,750.00$ & - & \\
\hline
\end{tabular}


Analyzing the various house financing products offered by Islamic banks in Malaysia, Siti \& Azira (2013) concluded that typically, the bank does not bear any risk regarding the ownership of the home or property. The legal title of the home or property lies with the customer from the beginning of the contract and the bank just acts as a trustee. Along the same lines, Shaikh (2006) comparing the similarities and differences in the operations of Islamic and conventional banking in the provision of house finance concluded that there is almost no dissimilarity in the substance of transactions, cash flows and liability. Even though contract mechanics stipulate that bank will be liable to bear any ownership related risks, but such are mitigated through insurance. Insurance cost is included in the rent amortization schedule and the customer has to agree on that schedule before bank buys property. Table 3 compares the features of conventional mortgage with Islamic mortgage financing.

Table 3: Comparison of Features

\begin{tabular}{lll}
\hline Features & Conventional Mortgage & Diminishing Musharakah \\
\hline Benchmark Rate & KIBOR & KIBOR \\
Basis of Inters / Rent & KIBOR & KIBOR \\
Nature of Installment & Interest + Principal Repayment & Rent + Sale of Units \\
Prepayment Penalty & Yes & Units sold at High Price \\
Rent + Sale contract & Dependent & Separated by promise \\
In subsequent years & Interest decreases & Rent decreases \\
In subsequent years & Principal repayment increases & More Units purchased \\
Changes in Interest/Rent & Based on KIBOR & Based on KIBOR \\
\hline
\end{tabular}

\section{Critical Issues in Diminishing Musharakah Structure}

It is an empirical fact that Islamic banks prefer to offer debt related products (Ismail, 2011). In practiced Islamic banking, taking an undertaking from the lessee is just like buying a put option (with put premium equal to zero) from the lessee who acts as a put option writer. What this essentially does is that it enables the Islamic bank to avoid market and price risk.

The Islamic bank only buys the house when it has obtained a unilateral undertaking from the client that is legally enforceable and which allows the bank to lock the subsequent lease contract and charge stipulated periodic installments before committing any of its funds.

Masri (2002) expressing the concern over using unilateral undertaking to mitigate risk writes:

"Some modern jurists have moved such a unilateral promise
(wa'd) from the category of voluntary offer (tabarru'āt) to that of 
commutative contracts, (mu'awadāt), so as to replace the contract. That is because these proponents have found that (Murabaha, i.e., a resale contract with specification of gain (cost plus original price) is not permissible, since it falls under the sale of goods that are not in one's possession (the goods are not in the bank's possession). So, they replaced the contract with the unilateral promise (wa'd), that is to say, they made the contract a unilateral promise (wa'd). Had they stopped at that point, and had the unilateral promise (wa'd) remained non-binding, there would not have arisen any problems; but, in fact, they went on to say, and herein lies the gravity of their position: we will make the unilateral promise (wa'd) binding-and so they went a long way in elaborating, amplifying, dissecting, and subcategorizing, until they filled people with the fear of not fulfilling a unilateral promise (wa'd) so much so that the binding unilateral promise (wa'd), which for them is permissible, came to replace the contract which is proscribed by Islamic law.

Then, in conclusion, the noted scholar writes:

"In summary, it is inadmissible for the unilateral promise (wa'd) as an alternative to a proscribed contract, such as selling goods that are not in one's possession, to be binding, because a binding unilateral promise (wa'd) is analogous to a contract. Any views for making it binding upon both or either parties, explicitly or implicitly, by virtue of a Memorandum of Understanding (MOU), a sideline agreement, or any other circumvention, are not founded on any legitimate basis."

Chaudhry (2006) also noted that a narrow juristic interpretation of the Shariah is followed, leaving aside the Tawhidi core. Ismail (2011) argued that growth in the industry has taken more precedence over Shariah compliance in letter and spirit.

Some authors have presented alternate proposals like Zubair (2011a) and Ebrahim (2009) for house finance. Zabair's diminishing balance method was criticized by Meera (2012) for being similar in nature to interest based mortgage. Ebrahim's (2009) proposal of using co-operatives could still not clearly answer how to avoid a loan transaction and hence justify the premium on loaned sum of money.

\section{Alternate Proposal for Interest Free House Finance}

In this section, we present an alternative proposal which will make the transaction look much more transparent and realistic.

If the above mentioned put option provision is reversed, the client would buy the call option and the financial institution will sell the call option i.e. acts as a call option writer. 
To make it conform to Islamic principles, call premium can be removed or if taken, it could be regarded as token amount for subsequent purchase of house. In case, if client does not exercise the call option, then, this amount will be returned. In this way, the upfront call premium, if taken, will be a valid consideration.

This alternative could work as follows:

a) The Islamic financial institution buys the house paying the house owner the full amount of the house. The Islamic financial institution is now the owner of the asset.

b) Then, the financial institution gives the house on rent to the client and the Islamic financial institution also enters into an options contract as the call option writer.

c) If the call buyer does not exercise the option, the options contract expires and the Islamic financial institution is in a position to give the house on rent again.

d) If the call buyer exercises the option, the Islamic financial institution gets the house price plus the rental income for the period before the expiration of the options contract.

The rent could be benchmarked using House Rent Index. The issue arises whether a fixed premium could be added or not. However, since the contract itself does not have any connection with interest or interest rate benchmark and the rent is charged as long as the house is in usable condition, it does not contradict with Islamic principles.

Furthermore, the proposal meets following specific objectives:

a) To allow people to break free from conventional mortgage if they feel that they are not able to keep paying installments. It is done by making them call option buyers and hence, they get a choice.

b) To achieve separation of tenancy and sale contract as it is a requirement in Islamic jurisprudence. This is achieved in Islamic finance currently through a unilateral undertaking which is legally enforceable. Hence, current mechanism to separate tenancy and sale are not ideal and are just legal solutions to the problem unlike this proposal.

c) To propose a mechanism that still allows the financial institution to have reasonable returns even when future prices are low and when they are high. Future prices will determine the client's decision to exercise or not to exercise the call option contract.

d) To propose a mechanism that still allows the client to have a place for living and an option to purchase the house at a fixed price rather than paying fixed installments until maturity. 
e) To propose a mechanism for setting rentals which reflects true market rent rather than linking it with an interest based benchmark. Hence, an alternative to LIBOR as a benchmark/pricing rule has also been provided by linking the rentals with House Rent Index.

No matter how high the price of option is, the customer would always be in a position not to pay higher than market prices. It is because the customer can decide not to exercise the call option.

\section{Analysis of Effects of the Proposal}

Apparently, it may seem unattractive to financial institution as the financial institution will have to take a certain risk this time, which all normal landlords take in house market. But, this proposal disallows the financial institution any differential and preferential treatment. Below, we mention some of the benefits that will accrue to the financial institution from the proposal:

a) Rent for some period could be fixed by linking it with rental benchmark. It can be changed later on. For the purpose of hedging, some advance rent could also be taken and this would be an alternative to upfront down-payment.

b) Rent could be set as a multiple of benchmark (House Rent Index), but that always depends on bargaining power of both the parties. There could be cap and floor just like in current practice.

c) Option price together with targeted rentals will enable the financial institution to cover its cost.

d) If house prices are increasing, the house rent will also increase. So, if prices are increasing, all benefit will not accrue to the lessee alone. With increase in rents, shareholders and rabb-ul-maal (depositors) of the financial institution will also benefit.

Adding to point c) above, we present the Consumer Price Index (CPI) values for Pakistan for the period 1973-2010 with base equal to 100 for CY2000 in Figure 3. It can be seen that prices increase exponentially. If a financial institution had provided financing in year 1991 for 20 years, then in 2011, if the house had increased in value by the CPI rate, the value of house will have been 5 times (increase of 400\%) of the 1991 value. This is just the capital gain. Rents are another source of income to the financial institution.

Figure 3: CPI Values from 1973-2011 (Base Year = 2000) 


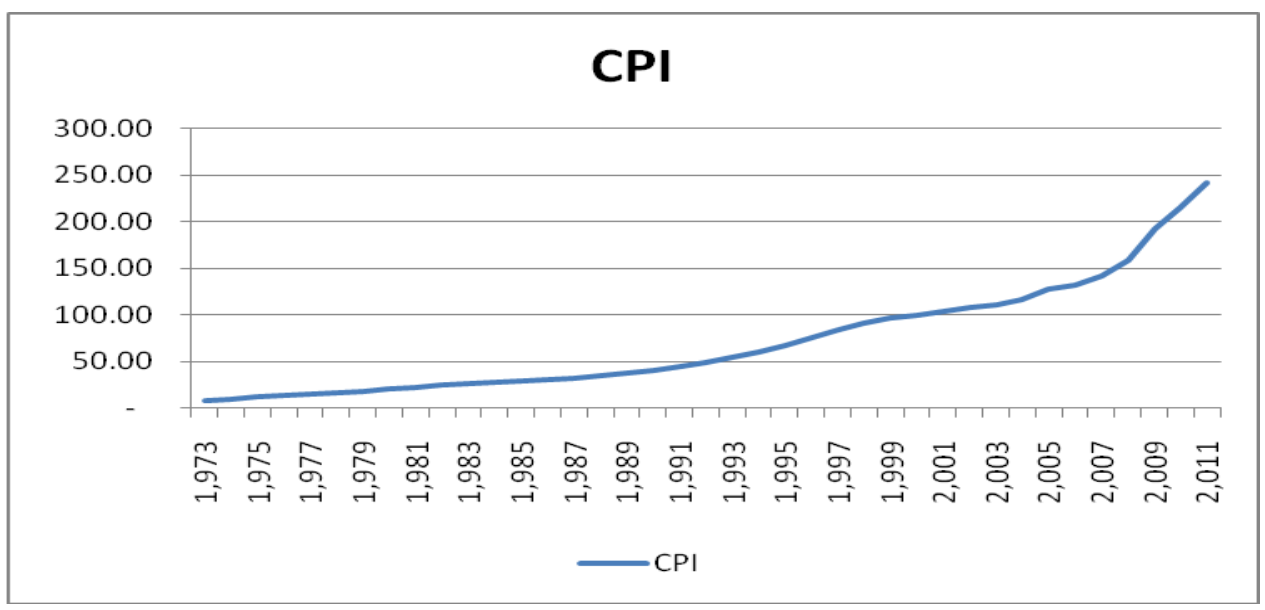

\section{Analysis Using Numerical Computations}

We take a numerical example to present necessary computations for the proposal. Let us say a client needs financing of Rs 5,000,000 for a 10 year period for purchasing an already built house. Inflation in the economy is expected to grow by $10 \%$ per annum. Monthly rent shall be paid by the client for the use of house owned by Islamic financial institution.

Let us suppose that the Islamic financial institution wants to receive ' $x$ ' from the total rents during the lease. Monthly rent can be calculated by:

Where,

$$
\text { Monthly Rent }=\left[\frac{x}{n * m}\right] * \text { Cost Price }
$$

' $x$ ' is the proportion of asset value that the financier wants to recover from the contract.

' $n$ ' is the period of lease in years.

' $m$ ' is the frequency of rent payment in a year.

Total rent can be computed from:

$$
\text { Total Rent }=\text { Montly Rent } x(n \times m)
$$

If we want to compute the real value (net of inflation) of total rents paid over the lease period, we can use:

Where 'i' will be the inflation rate.

$$
P V A=A\left[\frac{(1+i)^{n}-1}{i(1+i)^{n}}\right]
$$

We present two possible structures that can be used. In structure I, call option will be used and the strike price will be stated. In structure II, no call option will be used. The house will be sold at a market price with a floor that can be set at $100 \%$ historical cost of house or at other values. 
In Table 4, we present a numerical example of structure I. It can be seen that the bank will be able to earn substantial total cash flows choosing an appropriate strike price. Real value of cash flows could be more than historical investment when strike price is approximately more than $250 \%$ of the cost. It is to be noted that in recent years, banks have earned negative real returns on their loan portfolios in Pakistan with inflation rate being more than average lending rates. But, here, the bank can revise rentals based on inflation or based on house price index.

Table 4: Structure I Using Call Options

\begin{tabular}{|l|c|c|}
\hline \multicolumn{1}{|c|}{ Particulars } & Scaling Factor & \multicolumn{1}{c|}{ Values } \\
\hline Cost Price of House & & $5,000,000$ \\
\hline Period of Lease (in Years) & & 10 \\
\hline Period of Lease (in Months) & & 120 \\
\hline Total Asset Value Covered from Rents & & 0.50 \\
\hline Inflation Rate & & 0.12 \\
\hline & & \\
\hline Monthly Rental Value & & $20,833.33$ \\
\hline Total Rent Paid & & $2,500,000$ \\
\hline PV of Total Rent Paid & & $1,452,094$ \\
\hline & 2 & $10,000,000$ \\
\hline Strike Price (Asset Value: 100\%) & 3 & $15,000,000$ \\
\hline Strike Price (Asset Value: 125\%) & 5 & $25,000,000$ \\
\hline Strike Price (Asset Value: 150\%) & & \\
\hline & & $3,029,948$ \\
\hline Real Asset Value: (Strike Price = 200\% of Cost) & $4,544,922$ \\
\hline Real Asset Value: (Strike Price = 300\% of Cost) & & $7,574,869$ \\
\hline Real Asset Value: (Strike Price = 500\% of Cost) & \\
\hline & & $4,482,042$ \\
\hline Real Value of Total Cash Flows (Strike Price: 200\% of Cost) & & $5,997,016$ \\
\hline Real Value of Total Cash Flows (Strike Price: 300\% of Cost) & & $9,026,964$ \\
\hline Real Value of Total Cash Flows (Strike Price: 500\% of Cost) & & \\
\hline
\end{tabular}

In table 5, we present the results in Structure II. It can be seen that the bank will be able to earn substantial total cash flows choosing an appropriate minimum price of house. Real value of cash flows could be more than historical investment when market price is approximately more than $250 \%$ of the cost. We have shown before that if a bank had provided financing in year 1991 for 20 years, then in 2011, if the house had increased in value by the CPI rate, the value of house will have been 5 times (increase of $400 \%$ ) of the 1991 value. 
Table 5: Structure II Using Call Options

\begin{tabular}{|l|c|}
\hline \multicolumn{1}{|c|}{ Particulars } & Values \\
\hline Cost Price of House & $5,000,000$ \\
\hline Period of Lease (in Years) & 10 \\
\hline Period of Lease (in Months) & 120 \\
\hline Total Asset Value Covered from Rents & 0.5 \\
\hline Inflation Rate & 0.12 \\
\hline & \\
\hline Monthly Rental Value & $20,833.33$ \\
\hline Total Rent Paid & $2,500,000$ \\
\hline PV of Total Rent Paid & $1,452,094$ \\
\hline & \\
\hline Minimum Price (Asset Value: $250 \%)$ & $12,500,000$ \\
\hline Market Price & $6,000,000$ \\
\hline & \\
\hline Asset Value Received & $12,500,000$ \\
\hline Real Value of Asset Sold & $3,787,435$ \\
\hline Real Value of Total Cash Flows to Bank & $5,239,529$ \\
\hline
\end{tabular}

\section{Conclusion}

In this paper, we presented an alternate proposal for house finance. In our proposal, the Islamic bank buys the house paying the house owner the full amount of the house and becomes the owner. Then, the bank gives the house on rent to the client and the Islamic bank also enters into an options contract as the call option writer. If the call buyer does not exercise the option, the options contract expires and the Islamic bank is in a position to give the house on rent again. We presented numerical examples of computing rents in different scenarios and it seems that the proposal is robust in different scenarios. Furthermore, it is substantially and meaningfully different from conventional finance in form and substance. To implement the model on small scale first, Islamic financial institutions can fund residential areas with similar types of houses and prices. The market price in such areas is easy to identify and these areas comprise structured real estate with liquid secondary market.

\section{References}

Chaudhry, Masood ul Alam (2006) "What is the Scope of Islamic Economics and Finance?", Journal of Islamic Economics, Banking \& Finance. Vol 2 (1), pp.1 14.

Ebrahim, M. Shahid (2009), "Can an Islamic model of housing finance cooperative elevate the economic status of the underprivileged?", Journal, Elsevier, 72(3), pp. 864 - 883. 
Hasan, Zubair (2011a)."Islamic Home Finance in the Social Mirror", ISRA International Journal of Islamic Finance, 3 (1), pp. 7 - 24.

Hasan, Zubair (2012). "Mortgage contracts in Islamic home finance: Musharakah Mutanaqisah program vs. Zubair Diminishing Balance Model", MPRA Paper 39067, University Library of Munich, Germany.

Ismail, Abdul Ghaffar (2011) "The Theory of Islamic Banking: Look Back to Original Idea", Journal of Islamic Economics, Banking \& Finance. Vol 7 (3), pp. 9 - 22.

Ismail, Abdul Ghaffar (2011) "The Dilemma Facing Islamic Finance and Lessons Learned From the Global Financial Crisis", Journal of Islamic Economics, Banking \& Finance. Vol 7 (1), pp. 58 - 76.

Masri, Rafic Younus (2002). The Binding Unilateral Promise (wa'd) in Islamic Banking Operations: Is it Permissible for a Unilateral Promise (wa'd) to be Binding as an Alternative to a Proscribed Contract? J.KAU: Islamic Econ., Vol. 15, pp. 29-33.

Meera, A. K. M. \& Dzuljastri, A. R. (2009). "Home Financing through the Musharakah Mutanaqisah Contracts: Some Practical Issues", JKAU: Islamic Economics, 22 (1). pp. 3 - 27.

Meera, Ahmad Kameel M. (2012). "A Critique of the Dimnishing Balance Method of Islamic Home Financing", ISRA International Journal of Islamic Finance, 4 (2), pp. 7 - 23.

Shaikh, Imran Ali (2006), "Comparison of Diminishing Musharakah and Conventional House Financing Contracts", Market Forces, 2 (3).

Siti, F. Muhamad \& Azira, Hanani A.R. (2013). "An evaluation on Musharakah Mutanaqisah based house financing by Islamic banks in Malaysia", proceeding of the international conference on social science research, ICSSR 2013. 